\title{
Enhancing Public Participation in Public Health Offerings: Patient Preferences for Facilities in the Western Cape Province Using a Discrete Choice Experiment
}

\author{
Plaxcedes Chiwire ${ }^{1, *(D)}$, Charlotte Beaudart ${ }^{1}$, Silvia M. Evers ${ }^{1}$, Hassan Mahomed ${ }^{2}$ and Mickaël Hiligsmann ${ }^{1}$ \\ 1 Department of Health Services Research, CAPHRI Care and Public Health Research Institute, Maastricht \\ University, 6200 MD Maastricht, The Netherlands; c.beaudart@maastrichtuniversity.nl (C.B.); \\ s.evers@maastrichtuniversity.nl (S.M.E.); m.hiligsmann@maastrichtuniversity.nl (M.H.) \\ 2 Metro Health Services, Western Cape Government: Health and Division of Health Systems and Public Health, \\ Department of Global Health, Faculty of Medicine and Health Sciences, Stellenbosch University, \\ Stellenbosch 7505, South Africa; Hassan.Mahomed@westerncape.gov.za \\ * Correspondence: plaxcy@gmail.com
}

check for updates

Citation: Chiwire, P.; Beaudart, C.; Evers, S.M.; Mahomed, H.; Hiligsmann, M. Enhancing Public Participation in Public Health Offerings: Patient Preferences for Facilities in the Western Cape Province Using a Discrete Choice Experiment. Int. J. Environ. Res. Public Health 2022, 19, 590. https://doi.org/10.3390/ ijerph19010590

Academic Editors: Stephanie Stock and Gianfranco Damiani

Received: 3 December 2021 Accepted: 29 December 2021 Published: 5 January 2022

Publisher's Note: MDPI stays neutral with regard to jurisdictional claims in published maps and institutional affiliations.

Copyright: (c) 2022 by the authors. Licensee MDPI, Basel, Switzerland. This article is an open access article distributed under the terms and conditions of the Creative Commons Attribution (CC BY) license (https:/ / creativecommons.org/licenses/by/ $4.0 /)$.

\begin{abstract}
Understanding patients' preferences for health facilities could help decision makers in designing patient-centered services. Therefore, this study aims to understand how patients' willingness to trade for certain attributes affects the choice of public health facilities in the Western Cape province of Cape Town, South Africa. A discrete choice experiment was conducted in two community day centers (CDCs). Patients repetitively chose between two hypothetical health facilities that differed in six attributes: distance to facility, treatment by doctors vs. nurses, confidentiality during treatment, availability of medication, first visit (drop-in) waiting times, and appointment waiting times. The sample consisted of 463 participants. The findings showed that availability of medication (50.5\%), appointment waiting times (19.5\%), and first visit waiting times $(10.2 \%)$ were the most important factors for patients when choosing a health facility. In addition, respondents preferred shorter appointment and first visit waiting times $(<2 \mathrm{~h})$. These results identified important characteristics in choosing public health facilities in Cape Town. These public health facilities could be improved by including patient voices to inform operational and policy decisions in a low-income setting.
\end{abstract}

Keywords: discrete choice experiments; patient preferences; facility choice; health provider choice; stated preferences

\section{Introduction}

When people are unwell, the choice of where to seek medical care is influenced mainly by personal preferences, illness severity, and economic capacity [1,2]. The provision of quality health services is largely dependent on the sufficiency of the health workforce (in terms of numbers, the quality of skills they possess, how and where they are deployed, and how they are managed) [3]. The World Health Organization (WHO) argues that health systems are made of different components (organizations, institutions, and resources) that devote themselves to producing actions whose primary purpose is to improve health [4]. Most of the South African population access health services through government-run public clinics and hospitals. As South Africa moves to adopt National Health Insurance (NHI), the success of this process hinges on public healthcare reforms, which are critical to the delivery of high-quality, accessible, public-sector health services for universal coverage in the health system. Regardless of whether healthcare services become more affordable and available, people will not use them if the quality of these services is unacceptable [5]. Citizenry criticism of public healthcare is widely documented. As a result, several initiatives such as NHI Public Hearings have been carried out to capture concerns and try to improve the services offered by the government [6,7]. 
Public participation is widely regarded as the backbone of democracy in South Africa [8]. Several studies in the literature [3,8-11] have cited public participation as an instrument for establishing democracy and promoting unity between the government and the people. The aim of shifting decision making to a local level is to give citizens and their local representatives more power in public decision making. Thus, there is more participation in smaller geographic areas where mutual knowledge is greater, distances are shorter, and scales are smaller [11]. This could grant citizens greater influence on the formulation and implementation of health policies in the context of the national policy and healthcare framework, and the health system.

Community participation has widely been argued to be an important factor in improving health outcomes and the performance of health systems [10]. A relational skillset of intangible software, such as values, power, and communication, has been deemed crucial in fostering better community participation in health systems [11]. The inclusion of patient voices in policymaking is also increasingly gaining momentum in health technology assessments (HTA) [5,12-15]. Some studies note a lack of patient input in operations (day-to-day management) and treatment decisions, with healthcare providers continuing to make decisions for the provision of care on behalf of the patient $[13,16,17]$. It is essential to include patients, who are the users of health technology, in policymaking and day-to-day operational assessments. The outcomes following patient voice inclusion are likely to be more positive and beneficial for citizens. It is therefore important to elicit the preferences of patients using public health facilities. Several studies in the literature $[3,5,8,10,18-24]$ argued for the need for more research to be carried out to integrate community perspectives into the available evidence-based health systems.

The National Core Standards for health establishments in South Africa specifies six priority areas for improvement: staff values and attitudes, waiting times, cleanliness, patient safety, security, infection prevention, control, and availability of medicines and supplies [25]. Information on how patients value these priority areas and other factors are often not presented in a format that shows their conditional relative importance when weighed against each other. For this reason, there is limited knowledge of South African patients' preference weighting about choosing public health facilities. This is an important issue that influences decision making by management. The current paper, therefore, uses a discrete choice experiment to understand the conditional relative importance of various healthcare factors.

Discrete choice experiments (DCEs) are a stated preference method that has gained popularity when eliciting preferences for healthcare interventions and services. Even though there is a large body of work on stated preferences, only a few studies have been conducted regarding patients' choice of facility, specifically within public health care. A systematic review of DCEs used to elicit patient preferences for primary healthcare showed that most studies were American or European, and focused on general practitioner (GP) consultations, [26] while Chinese studies appeared to focus primarily on the public health preferences of rural populations [27-30]. Only one South African DCE of public health facility preferences was identified [5]. This study suggested that treatment by doctors versus nurses, availability of medication, staff attitudes, waiting times, transport costs, expert advice, and examination are important factors influencing the choice of public health facilities. To the best of our knowledge, our study is the second DCE carried out in South Africa, focusing on patients attending public health facilities, contrary to Honda et al. (2015), who interviewed people outside the facility [5].

The present study aims to incorporate patient voices to identify areas in which the experience of care at public health facilities can be improved. The purpose is to facilitate demand for services and to increase patient satisfaction. The study uses a DCE to address patient preferences in the light of the proposed implementation of National Health Insurance in South Africa [31]. 


\section{Methods}

\subsection{Discrete Choice Experiments}

Research regarding patients' preferences of the attributes mentioned above has been limited to quantitative and qualitative studies that look at the patients' opinions of each attribute separately. Therefore, a DCE study was undertaken with the aim of better understanding patients' willingness to trade off some of these attributes, which may affect their choice and attendance at public health facilities.

\subsection{Study Design and Sampling}

Selection of Attributes and Attribute Levels

The study followed the International Society for Pharmacoeconomics and Outcomes Research (ISPOR) conjoint analysis guidelines [32]. The guidelines provide researchers with the necessary steps for conducting a conjoint analysis. A step-wise approach [33] was followed when selecting attributes and attribute levels. This multi-step approach included a literature review, stakeholder consultations, and focus group discussions (FGDs) using the nominal group technique (NGT). The identification and prioritization of attributes related to choosing healthcare facilities are reported in Chiwire et al. (2021) [34]. The same identification and prioritization protocols were used for this DCE. Five candidate attributes were chosen as top priorities following the participants' responses to the ranking and weighting process: distance ranked top of the list, followed by treatment by doctors, confidentiality during treatment, availability of medication, waiting times, and treatment by nurses, respectively. The attributes were divided into structural dimensions (distance to facility, waiting times, availability of drugs) and process dimensions (confidentiality during treatment and treatment by nurses or doctors) as per Donabedian's healthcare quality model [26].

The list of attributes and attribute levels was finalized through consultation with the research team and facilities management team. For example, the teams agreed to split waiting times into two attributes due to the nature of the services offered at the Community Day Centers (CDCs) - due to high demand, patients can be instructed to return on a different day so that more urgent cases can be prioritized. Additionally, chronically ill patients presenting for their bi-annual check-up were most likely to have an appointment. Table 1 details the final list of attributes and levels.

\subsection{Questionnaire Design and Sample Size}

As it is not very efficient to provide all possible combinations of these patient attributes, a Bayesian D-efficient statistical design (Ngene software) was used to reduce the number of choice sets. In addition, the design aimed to maximize the precision of the estimated parameters for a given number of choice questions by including a priori information about the sign and value of the parameters.

In total, 24 binary choice sets were developed and divided into two versions, namely, questionnaire 1 with 12 choice sets and questionnaire 2 with the remaining 12 . Participants were required to choose the alternative they preferred: facility A or facility B. Thus, each patient received 12 choice sets. Visual representations were used to facilitate patient understanding. The questionnaire was initially developed in English and then translated into Afrikaans and Xhosa. Figure 1 shows an example of a choice set.

The final questionnaire included the DCE, a willingness-to-pay section following another paper [35], and sociodemographic information. The DCE section started with a description of the task, a list of all attributes and levels, and an example of a choice task. A pilot study was conducted for face validity with 7 participants at Bothasig CDC to determine the feasibility of using the questionnaires in their original form, and to estimate the ease at which the participants could answer the questions. Only a few minor changes were made. The questionnaires were handed out to the clients. 
Table 1. Attributes, definition, and attribute levels describing facility choice preferences in the DCE.

\begin{tabular}{|c|c|c|}
\hline Attributes & Definition of Attributes & Attribute \\
\hline Distance to CDC & $\begin{array}{l}\text { How far for patients to travel to } \\
\text { the community day center (CDC) } \\
\text { in kilometers from their home. }\end{array}$ & $\begin{array}{l}\text { Less than } 3 \mathrm{~km} \\
\text { Between } 3-5 \mathrm{~km} \\
\text { Between } 5-10 \mathrm{~km} \\
\text { More than } 10 \mathrm{~km}\end{array}$ \\
\hline Confidentiality during treatment & $\begin{array}{l}\text { Consultation is carried out behind } \\
\text { closed doors, without other } \\
\text { patients and staff hearing. }\end{array}$ & $\begin{array}{l}\text { Other patients and staff cannot } \\
\text { hear the consultation } \\
\text { Other patients and staff can hear } \\
\text { the consultation }\end{array}$ \\
\hline $\begin{array}{l}\text { Waiting time for the first visit to } \\
\text { the facility (without an } \\
\text { appointment) }\end{array}$ & $\begin{array}{l}\text { How long does it take to consult } \\
\text { with the doctor or nurse after } \\
\text { entering the CDC. If the first visit } \\
\text { is for a particular ailment, they } \\
\text { will give a diagnosis. }\end{array}$ & $\begin{array}{c}2 \mathrm{~h} \\
4 \mathrm{~h} \\
6 \mathrm{~h} \\
\text { Different day than the } \\
\text { appointment }\end{array}$ \\
\hline Waiting time with an appointment & $\begin{array}{l}\text { How long does it take to see the } \\
\text { doctor or nurse after entering the } \\
\text { CDC with a pre-booked } \\
\text { appointment? }\end{array}$ & $\begin{array}{l}2 \mathrm{~h} \\
4 \mathrm{~h} \\
6 \mathrm{~h} \\
8 \mathrm{~h}\end{array}$ \\
\hline Treatment offered by & $\begin{array}{c}\text { Which staff member provides a } \\
\text { diagnosis. }\end{array}$ & $\begin{array}{l}\text { Doctor } \\
\text { Nurse } \\
\end{array}$ \\
\hline $\begin{array}{l}\text { Availability of required } \\
\text { medication }\end{array}$ & $\begin{array}{l}\text { The patient receives the } \\
\text { medication prescribed at the CDC. }\end{array}$ & $\begin{array}{l}\text { All the required medication is } \\
\text { available } \\
\text { Most of the required medication is } \\
\text { available } \\
\text { Some of the required medication } \\
\text { is available }\end{array}$ \\
\hline
\end{tabular}

Choice Set 1: Please indicate your preferred facility by crossing one box.

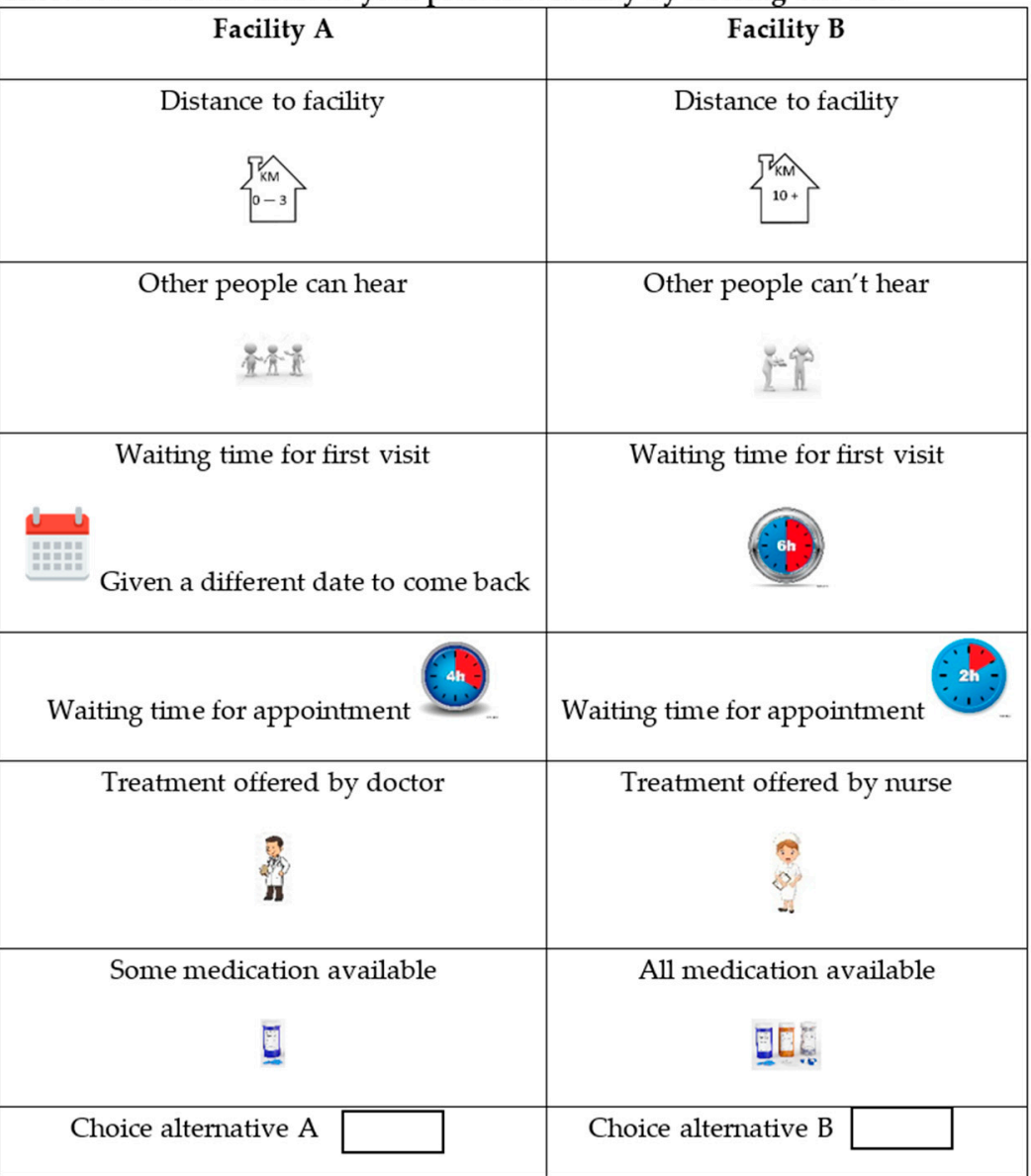

Figure 1. Example of a choice set in the DCE questionnaires. 
Regarding sample size, the requirements of DCEs are not uniformly determined. The Lancsar and Louver method [36], advises at least 20-30 respondents/observations per choice set to provide precise parameter estimates. To strengthen the internal validity of the results, the literature recommends increasing sample size as well as the number of hypothetical scenarios [36-38]. Thus, guided by other studies, and to reduce sampling error, 200-250 respondents were decided to be sufficient for this study. Hence, a sample of 500 was recruited, with 250 participants at each facility.

\subsection{Setting and Participants}

The DCE was conducted in the South African city of Cape Town. The target population was clientele of primary health facilities at community day centers (CDCs) in the Northern and Tygerberg sub-structures (a part of the city containing 2 out of 8 subdistricts). The studied population and health facilities were identified through consultation with the Northern-Tygerberg substructure team, comprised of the sub-structure director and 3 primary health care managers. Following this, Goodwood CDC and Bothasig CDC were selected as study sites. Bothasig is in a more affluent area compared with Goodwood. The sites were also chosen due to similarities in their offered care package, reducing selection bias in facility choice. Community day centers (CDCs) in South Africa offer a comprehensive primary health care package (antenatal care, termination of pregnancy, reproductive health, chronic diseases and care, TB care, People with HIV/AIDS, mental health, oral health, rehabilitation and disability services, environmental health, occupational health, casualty, and maternity).

The participants were adult males and females aged 18 or above. All were patients accessing the Bothasig or Goodwood CDC public health facilities for any of the aforementioned services which are in the primary health comprehensive package. The participants were approached as they waited for consultation in the reception, pharmacy, or doctors waiting rooms. Some patients declined participation due to fear of missing their consultation; these participants were replaced. The sample is thus a convenience sample in response to the health services' specific target. The findings would provide more broadly applicable information suited for decision making. It could also guide the selection of a more considerable, more representative study within the Western Cape.

\section{Analysis}

Analysis of the DCE was carried out using Nlogit software, version 5.0 (Econometric Software, Inc, NY, USA). First, a random parameter logit model or a latent class model were chosen for analyzing the choice observations. A random parameter logit model assumes that parameters are randomly distributed in the population, and captures heterogeneity by estimating the standard deviation of the parameters' distribution [5,39-41]. All attributes were categorical. The constant was included in the model to test for a systematic preference for either facility. Second, all parameters were specified as random (i.e., normal distributions) to account for heterogeneity, and 2000 Halton draws were conducted.

Effect coding was used to describe all categorical attributes. The reference/omitted levels were distance over $10 \mathrm{~km}$; people can hear the conversation with nurses; given a date for appointment; waiting time with an appointment- $8 \mathrm{~h}$; treatment by a nurse; and some of the required medication is available. These were calculated as a negative sum of the attribute levels' non-omitted coefficients and normalized to zero. The preference weights are relative to the mean effect of the different attribute levels and coefficients signs; the attribute preferences are either positive or negative compared with the mean. The conditional relative importance of each attribute was estimated using the beta-coefficients range for each attribute. Thereafter, interaction model analyses were conducted for subgroups related to sociodemographic variables (age, gender, and facility). 


\section{Ethical Considerations}

The Health Research Ethics Committee of Stellenbosch University approved the study. In line with the Western Cape Government's research guidelines, approval for facilities access was granted by the Western Cape Government Provincial Health Research Committee. The study adhered to the Declaration of Helsinki principles. All participants were required to sign consent forms before completing the questionnaires.

\section{Results}

A total of 500 participants completed the DCE questions. Questionnaires that were incomplete, or filled out by participants who were under 18, were not included. This resulted in a final sample of 463 (232 at Bothasig and 231 at Goodwood). Unfortunately, no information about the response rate was recorded. Overall, the respondents' demographic characteristics showed that most of the participants were female $(61 \%), 35$ years or above (59\%), educated to grade 8-12 (high school) (64\%), and unemployed (44\%). Please refer to Table 2 for more information.

Participant characteristics were similar at both facilities. In both cases, more females than males answered the questionnaire. Most of the participants were married or in a partnership (46\% at both facilities), and the proportion of singles was similar (35\% and 36\%, respectively). Students accounted for $7 \%$ at both facilities. Most participants traveled for 15-30 min to reach their local facility. However, several characteristics also differed between facilities: fifty percent of participants at Goodwood were 18-34 years old, while at Bothasig the majority was 35 or above. Half of the participants at Goodwood were unemployed, while at Bothasig, $64 \%$ were either formally employed or self-employed. Most participants at Bothasig were seeking care for a one-off condition, while at Goodwood, there were similar proportions of one-off patients and chronically ill patients. The visiting frequency was most commonly 1-12 months at Bothasig and >2 years at Goodwood. The mode of transport was most commonly walking for Goodwood participants, and private car for Bothasig participants. Please refer to Appendix A for more information.

Table 2. Respondents' demographic characteristics.

\begin{tabular}{|c|c|c|c|c|c|}
\hline \multirow{2}{*}{ Type of Factors } & \multirow{2}{*}{ Variables } & \multirow{2}{*}{ All $(n=466)$} & \multicolumn{3}{|c|}{ Facility } \\
\hline & & & $\begin{array}{c}\text { Bothasig CDC } \\
(n=230)\end{array}$ & $\begin{array}{c}\text { Goodwood CDC } \\
(n=236)\end{array}$ & $p$-Value \\
\hline \multirow{15}{*}{$\begin{array}{l}\text { Sociodemographic } \\
\text { Factors }\end{array}$} & Sex $(\%)$ & & & & \\
\hline & Male & $179(38.4)$ & $81(35.2)$ & $98(41.5)$ & 0.024 \\
\hline & Female & $282(60.5)$ & $149(64.8)$ & $133(56.4)$ & \\
\hline & Age Group (\%) & & & & \\
\hline & $18-34$ & $192(41.2)$ & $114(49.6)$ & $78(33.1)$ & $<0.001$ \\
\hline & $35+$ & $274(58.8)$ & $116(50.4)$ & $158(66.9)$ & \\
\hline & Marital Status (\%) & & & & \\
\hline & Single & $164(35.2)$ & $82(35.7)$ & $82(34.7)$ & 0.931 \\
\hline & Married or partnership & $214(45.9)$ & $106(46.1)$ & $108(45.8)$ & \\
\hline & Widowed & $28(6.0)$ & $13(5.7)$ & $15(6.4)$ & \\
\hline & Divorced & $46(9.9)$ & $22(9.6)$ & $24(10.2)$ & \\
\hline & Separated & $6(1.3)$ & $4(1.7)$ & $2(0.8)$ & \\
\hline & Education (\%) & & & & \\
\hline & Grade $0-7$ & $32(6.9)$ & $12(5.2)$ & $20(8.5)$ & 0.022 \\
\hline & Grade 8-12 & $296(63.5)$ & 137 (59.6) & $159(67.4)$ & \\
\hline
\end{tabular}


Table 2. Cont.

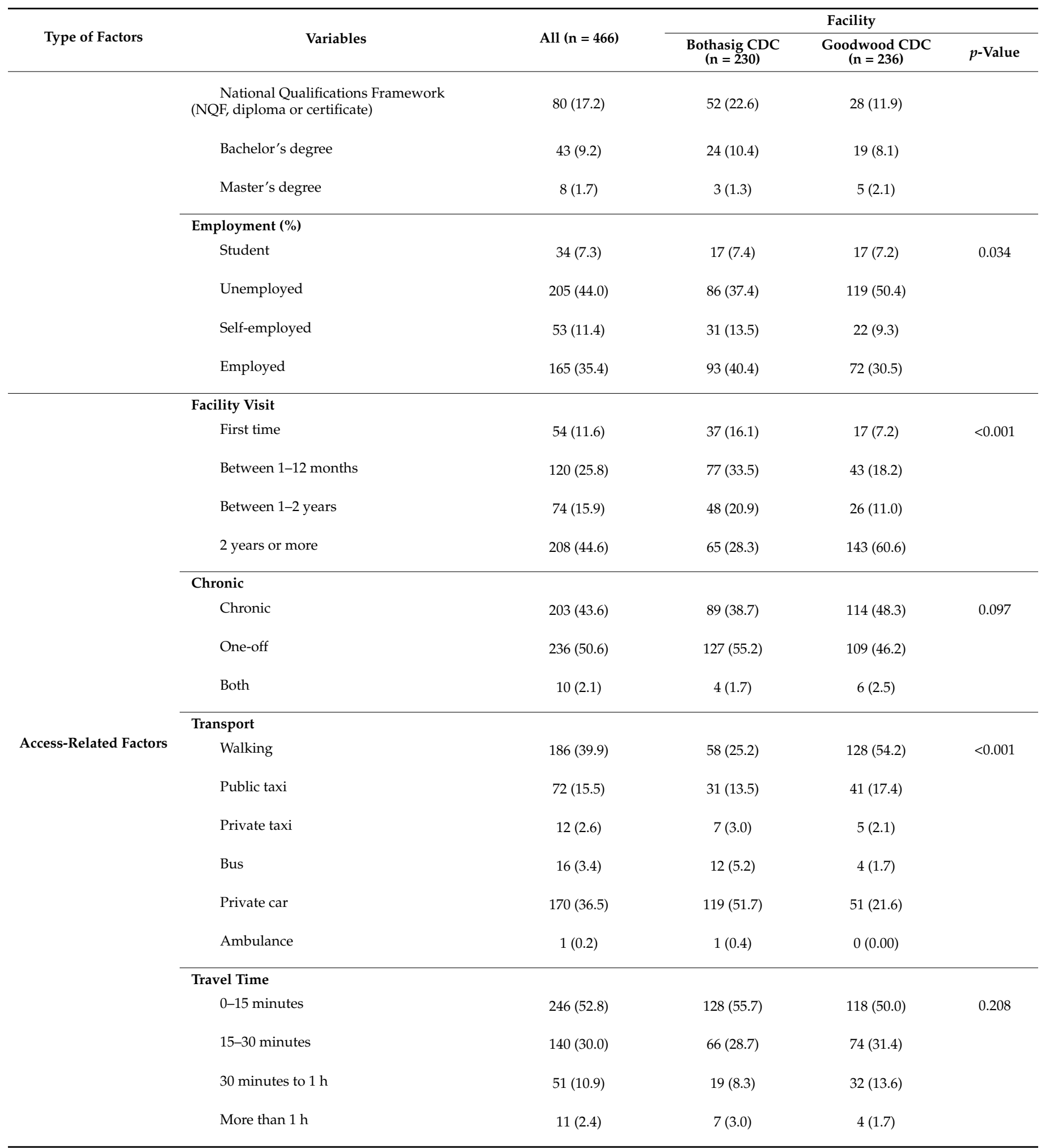

p-values obtained with $\mathrm{Chi}^{2}$ test; 5 missing data for gender; 8 missing data for marital status; 7 missing data for education; 9 missing data for employment; 10 missing data for facility visit; 16 missing data for chronic; 9 missing data for transport; and 17 missing data for travel time (+1 data entry error/coded as 5). 


\section{Patient Preferences}

The main results of the patients' preferences, obtained using a random parameters logit model, are presented in Table 3 and Figure 2. At least one level of each attribute was significant at $p<0.05$. An assessment of the attributes according to conditional relative importance shows that the availability of medication $(50.5 \%)$ was the most important attribute for patients when selecting a facility, followed by appointment waiting times $(19.5 \%)$, and first visit waiting times (10.4\%). Conversely, going by relative importance, the least important attributes when selecting a facility were treatment by doctors vs. nurses $(8.2 \%)$, distance to the health facility $(6.7 \%)$, and confidentiality $(4.6 \%)$.

Respondents preferred facilities where all required medication was available to facilities where only some medication was available. Respondents also preferred short appointment waiting times $(2 \mathrm{~h})$, with preference reducing as the waiting time increased. Similar findings were also observed for first visits, where short waiting times $(2 \mathrm{~h})$ were preferred to longer ones. In addition, respondents preferred to be treated by doctors rather than nurses. They also preferred absolute confidentiality-no one else being able to hear their consultation-compared with no confidentiality. Finally, the positive coefficient when the attribute of distance to the health facility was less than $3 \mathrm{~km}$ shows that respondents preferred traveling shorter distances, rather than longer distances. Standard deviations were, however, significant for all attributes except for treatment by doctors vs. nurses, showing that there was significant variation/heterogeneity within each attribute/level across respondents.

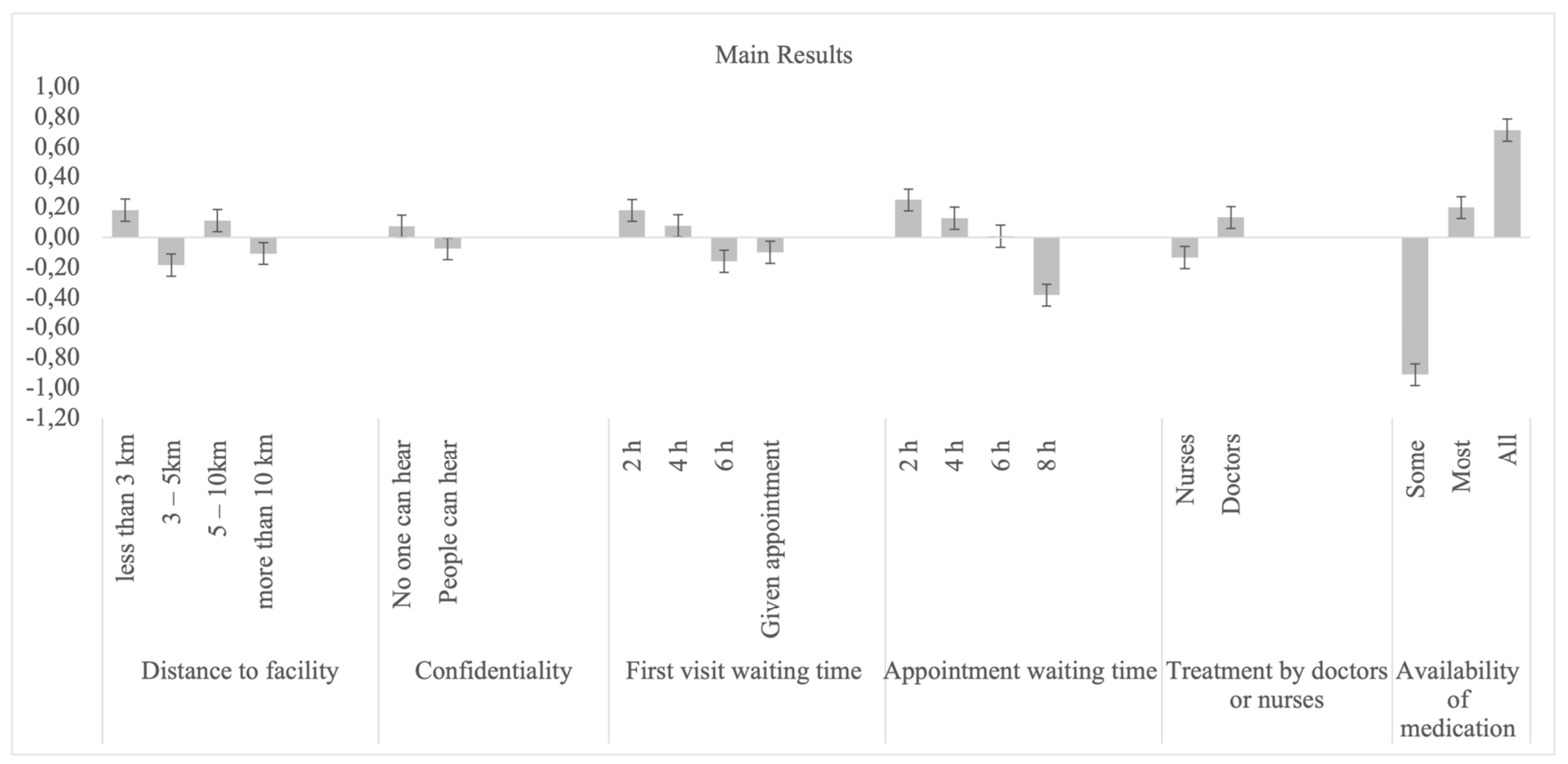

Figure 2. Main results random parameters logit model with a standard deviation. 
Table 3. Main results random parameters logit model.

\begin{tabular}{|c|c|c|c|}
\hline Overall Results & \multirow{2}{*}{ Coefficient } & \multirow{2}{*}{ Estimated Standard Deviation } & \multirow{2}{*}{ Relative Importance } \\
\hline Attribute/Level & & & \\
\hline Constant (non-random parameter) & $0.07^{* *}(0.01$ to 0.14$)$ & & \\
\hline \multicolumn{4}{|l|}{ Distance } \\
\hline Distance to facility is less than $3 \mathrm{~km}$ & $0.18^{* * *}(0.67$ to 0.29$)$ & $0.23^{* * *}$ & \\
\hline Distance to facility is $3-5 \mathrm{~km}$ away from home & $-0.18^{* * *}(-0.27$ to -0.10$)$ & $0.36^{* * *}$ & \\
\hline Distance to facility is $5-10 \mathrm{~km}$ away from home & $0.11^{* * *}(0.03$ to 0.18$)$ & $0.19 * *$ & \\
\hline Distance to facility is more than $10 \mathrm{~km}$ & $-0.11^{* *}(-0.21$ to -0.01$)$ & & $6.7 \%$ \\
\hline
\end{tabular}

\section{Confidentiality}

No one can hear your conversation with the nurses

$0.07^{* * *}(0.02$ to 0.13$) \quad 0.22^{* * *}$

People can hear conversation with nurses

$-0.07(-0.13$ to -0.02$)$

\section{First visit waiting time}

First visit waiting time $2 \mathrm{~h}$

$0.12^{* * *}(0.08$ to 0.27$)$

0.20 **

First visit waiting time $4 \mathrm{~h}$

$0.08 *(-0.00$ to 0.16$)$

$0.30^{* * *}$

First visit waiting time $6 \mathrm{~h}$

$-0.16(-0.23$ to -0.08$)$

0.1

Given different date appointment

$-0.10(-0.22$ to 0.02$)$

$10.4 \%$

\section{Appointment waiting time}

Appointment waiting time $2 \mathrm{~h}$

$0.25^{* * *}(0.14$ to 0.35$)$

$0.23^{* * *}$

Appointment waiting time $4 \mathrm{~h}$

$0.13^{* * *}(0.05$ to 0.20$)$

$0.19^{* *}$

Appointment waiting time $6 \mathrm{~h}$

$0.01(-0.07$ to 0.09$)$

0.01

Appointment waiting time $8 \mathrm{~h}$

$-0.38^{* * *}(-0.49$ to -0.27$)$

$19.5 \%$

\section{Treatment by doctors or nurses \\ Treatment offered by nurses \\ Treatment offered by doctor}

$-0.13(-0.23$ to -0.04$)$

$0.13^{* * *}(0.04$ to 0.23$)$

0.1

$8.2 \%$

\section{Availability of medication}

Some of the medication required is available

$-0.91^{* * *}(-1.10$ to -0.72$)$

Most of the required medication is available

$0.20(0.14$ to 0.26$)$

All medication required is available

$0.71^{* * *}(0.55$ to 0.88$)$

$0.97^{* * *}$

$50.5 \%$

Replications for simulated probs. $=1000$

RPL model with panel has 466 groups

Fixed number of observations. / group $=12$

Number of observations. $=5592$, skipped 80 observations
Log likelihood function -3618.69568

Restricted log likelihood

-3820.62726
Chi squared [27] $(p=0.000) 403.86315$

Significance level 0.00000 McFadden pseudo R-squared
0.0528530

Estimation based on $n=5512, \mathrm{~K}=27$

Inf.Cr.AIC $=7291.4$ AIC $/ n=1.323$

*** Significant at $0.01 ; * *$ Significant at $0.05 ;$ and * Significant at 0.1 . 


\section{Sub-Group Analysis}

Sub-group analysis was conducted on age, gender, and facilities. Significant differences were observed for the gender and facilities classes but not for the age groups.

\subsection{Males vs. Females}

The health facility preferences by males and females are presented in Table 4 and Appendix C. The interaction model revealed significant differences in waiting times and confidentiality. Females had slightly more preference for first visits and appointment shorter waiting times $(2 \mathrm{~h})$ than men. In addition, females reported a higher preference for confidentiality compared with men.

\subsection{Facilities: Goodwood vs. Bothasig}

Table 5 and Appendix D show the results for the facilities sub-group analysis. Goodwood participants had a much higher relative importance for medication availability $(62 \%)$ than Bothasig (19\%). Other attributes' relative importance was internally evenly spread for Bothasig except for confidentiality. The interaction model revealed significant differences in the availability of medication. Goodwood had a significantly stronger preference for all the medication being available $(p=0.00)$ compared with Bothasig. Similarly, for most of the medication being available $(p=0.03)$. Bothasig had a significantly higher preference for treatment to be offered by a doctor $(p=0.02)$ than Goodwood.

The distance between 3-5 $\mathrm{km}$ was significantly less preferred at Goodwood compared with Bothasig. Respondents at Goodwood showed significantly stronger preference for confidentiality than at Bothasig. Both facilities preferred short first visit waiting times $(2 \mathrm{~h})$, with Bothasig having slightly more preference. As the times increased to $6 \mathrm{~h}$, both facilities reduced preference, with a stronger negative preference at Goodwood than Bothasig. 
Table 4. Differences between male and female respondents in preferences for facilities in the Western Cape province.

\begin{tabular}{|c|c|c|c|c|c|c|c|}
\hline \multirow{2}{*}{$\begin{array}{c}\text { Sub-Group Gender } \\
\text { Attribute/Level }\end{array}$} & \multicolumn{3}{|c|}{ Male } & \multicolumn{3}{|c|}{ Female } & \multirow{2}{*}{$\begin{array}{l}\text { Interaction Gender } \\
\text { Significance } p \text {-Value }\end{array}$} \\
\hline & Coefficient & $\begin{array}{c}\text { Estimated Standard } \\
\text { Deviation }\end{array}$ & $\begin{array}{c}\text { Relative } \\
\text { Importance }\end{array}$ & Coefficient & $\begin{array}{c}\text { Estimated Standard } \\
\text { Deviation }\end{array}$ & $\begin{array}{c}\text { Relative } \\
\text { Importance }\end{array}$ & \\
\hline Constant (non-random parameter) & $0.07(-0.03$ to 0.18$)$ & & & $0.07 *(-0.01$ to 0.16$)$ & & & 0.15 \\
\hline \multicolumn{8}{|l|}{ Distance } \\
\hline Distance to facility is less than $3 \mathrm{~km}$ & $0.09(-0.10$ to 0.28$)$ & $0.41^{* * *}$ & & $0.24^{* * *}(0.10$ to 0.39$)$ & 0.15 & & 0.18 \\
\hline Distance to facility is $3-5 \mathrm{~km}$ away from home & $-0.16^{* *}(-0.29$ to -0.02$)$ & $0.35^{* * *}$ & & $-0.20^{* * *}(-0.30$ to -0.9$)$ & $0.36^{* * *}$ & & 0.67 \\
\hline Distance to facility is $5-10 \mathrm{~km}$ away from home & $0.13 * *(0.00$ to 0.25$)$ & 0.17 & & $0.09(-0.00$ to 0.19$)$ & $0.22 * *$ & & 0.65 \\
\hline Distance to facility is more than $10 \mathrm{~km}$ & $-0.06(-0.22$ to 0.10$)$ & & $11.4 \%$ & $-0.13 * *(-0.25$ to -0.01$)$ & & $8 \%$ & \\
\hline \multicolumn{8}{|l|}{ Confidentiality } \\
\hline $\begin{array}{l}\text { No one can hear your conversation with the } \\
\text { nurses }\end{array}$ & $0.01(-0.07$ to 0.09$)$ & $0.18^{* * *}$ & & $0.12 * * *(0.05$ to 0.19$)$ & $0.26^{* * *}$ & & $0.06^{*}$ \\
\hline People can hear conversation with nurses & $-0.01(-0.09$ to 0.07$)$ & & $0.8 \%$ & $-0.12(-0.19$ to -0.05$)$ & & $6 \%$ & \\
\hline \multicolumn{8}{|l|}{ First visit waiting time } \\
\hline First visit waiting time $2 \mathrm{~h}$ & $0.05(-0.10$ to 0.21$)$ & $0.24 * *$ & & $0.27^{* * *}(0.14$ to 0.39$)$ & $0.20 *$ & & $0.03 * *$ \\
\hline First visit waiting time $6 \mathrm{~h}$ & $0.10(-0.22$ to 0.02$)$ & 0.11 & & $0.19^{* * *}(-0.09$ to 0.11$)$ & 0.11 & & 0.23 \\
\hline Given different date appointment & $-0.32 * *(-0.53$ to -0.11$)$ & & $14.6 \%$ & $-0.12(-0.28$ to 0.04$)$ & & $12 \%$ & \\
\hline \multicolumn{8}{|l|}{ Appointment Waiting time } \\
\hline Appointment waiting time $2 \mathrm{~h}$ & $0.10(-0.63$ to 0.27$)$ & 0.21 & & $0.34^{* * *}(0.20$ to 0.47$)$ & 0.21 & & $0.04^{* *}$ \\
\hline Appointment waiting time $4 \mathrm{~h}$ & $0.14 * *(0.02$ to 0.27$)$ & $0.34^{* * *}$ & & $0.12 * *(0.02$ to 0.22$)$ & 0.19 & & 0.78 \\
\hline Appointment waiting time $6 \mathrm{~h}$ & -0.01 (0.14 to 0.12$)$ & 0.13 & & $0.01(-0.09$ to 0.11$)$ & 0.00 & & 0.88 \\
\hline Appointment waiting time $8 \mathrm{~h}$ & $-0.23^{* *}(-0.41$ to -0.05$)$ & & $14.6 \%$ & $-0.47^{* * *}(-0.61$ to -0.33$)$ & & $21 \%$ & \\
\hline \multicolumn{8}{|l|}{ Treatment by doctors or nurses } \\
\hline Treatment offered by nurses & $-0.07(-0.23$ to 0.08$)$ & & & $-0.17(-0.30$ to -0.05$)$ & & & \\
\hline Treatment offered by doctor & $0.07(-0.08$ to 0.23$)$ & 0.13 & $5.5 \%$ & $0.17^{* * *}(0.05$ to 0.30$)$ & 0.12 & $9 \%$ & 0.34 \\
\hline
\end{tabular}


Table 4. Cont.

\begin{tabular}{|c|c|c|c|c|c|c|c|}
\hline Sub-Group Gender & & Male & & & Female & & Interaction Gender \\
\hline Attribute/Level & Coefficient & $\begin{array}{c}\text { Estimated Standard } \\
\text { Deviation }\end{array}$ & $\begin{array}{c}\text { Relative } \\
\text { Importance }\end{array}$ & Coefficient & $\begin{array}{c}\text { Estimated Standard } \\
\text { Deviation }\end{array}$ & $\begin{array}{c}\text { Relative } \\
\text { Importance }\end{array}$ & Significance $p$-Value \\
\hline \multicolumn{8}{|l|}{ Availability of medication } \\
\hline Some of the medication required is available & $-0.77(0.47$ to 1.07$)$ & & & $-0.87(0.62$ to 1.12$)$ & & & \\
\hline Most of the required medication is available & $0.19^{* * *}(0.10$ to 0.29$)$ & $0.23 * * *$ & & $0.10^{* * *}(0.12$ to 0.28$)$ & $0.29^{* * *}$ & & 0.97 \\
\hline All medication required is available & $0.58^{* * *}(0.32$ to 0.84$)$ & $0.98^{* * *}$ & $53.1 \%$ & $0.77^{* * *}(0.12$ to 0.28$)$ & $1.00^{* * *}$ & $43 \%$ & 0.28 \\
\hline
\end{tabular}

${ }^{* * *}$ Significant at $0.01 ; * *$ Significant at $0.05 ;$ and ${ }^{*}$ Significant at 0.1 .

Table 5. Differences between Goodwood and Bothasig respondents in preferences for facilities in the Western Cape province.

\begin{tabular}{|c|c|c|c|c|c|c|c|}
\hline \multirow{2}{*}{$\begin{array}{c}\text { Sub-Group Facilities } \\
\text { Attribute/Level }\end{array}$} & \multicolumn{3}{|c|}{ Goodwood } & \multicolumn{3}{|c|}{ Bothasig } & \multirow{2}{*}{$\begin{array}{r}\text { Interaction Facility } \\
\text { Significance } p \text {-Value }\end{array}$} \\
\hline & Coefficient & $\begin{array}{c}\text { Estimated Standard } \\
\text { Deviation }\end{array}$ & $\begin{array}{c}\text { Relative } \\
\text { Importance }\end{array}$ & Coefficient & $\begin{array}{c}\text { Estimated Standard } \\
\text { Deviation }\end{array}$ & $\begin{array}{c}\text { Relative } \\
\text { Importance }\end{array}$ & \\
\hline Constant (non-random parameter) & $0.10 *(-0.00$ to 0.19$)$ & & & $0.06(-0.03$ to 0.15$)$ & & & 0.17 \\
\hline \multicolumn{8}{|l|}{ Distance } \\
\hline Distance to facility is less than $3 \mathrm{~km}$ & $0.25^{* * *}(0.82$ to 0.42$)$ & 0.17 & & $0.09(-0.07$ to 0.25$)$ & $0.32 * * *$ & & 0.18 \\
\hline Distance to facility is $3-5 \mathrm{~km}$ away from home & $-0.29^{* * *}(-0.43$ to -0.53$)$ & $0.63 * * *$ & & $-0.07(-0.18$ to 0.04$)$ & 0.01 & & $0.01 * * *$ \\
\hline Distance to facility is $5-10 \mathrm{~km}$ away from home & $0.12 * *(0.01$ to 0.23$)$ & 0.22 ** & & $0.11 * *(0.00$ to 0.22$)$ & $0.21 * *$ & & 0.98 \\
\hline Distance to facility is more than $10 \mathrm{~km}$ & $-0.08(-0.23$ to 0.07$)$ & & $11.3 \%$ & $-0.13 *(-0.27$ to 0.01$)$ & & $10 \%$ & \\
\hline \multicolumn{8}{|l|}{ Confidentiality } \\
\hline No one can hear your conversation with the nurses & $0.16^{* * *}(0.09$ to 0.24$)$ & 0.08 & & $0.00(-0.08$ to 0.08$)$ & $0.29 * * *$ & & $0.02 * *$ \\
\hline People can hear conversation with nurses & $-0.16(-0.24$ to -0.09$)$ & & $6.7 \%$ & $0.00(-0.08$ to 0.08$)$ & & - & \\
\hline \multicolumn{8}{|l|}{ First visit waiting time } \\
\hline First visit waiting time $2 \mathrm{~h}$ & $0.07(-0.06$ to 0.21$)$ & 0.05 & & $0.29^{* * *}(0.15$ to 0.44$)$ & $0.35^{* * *}$ & & $0.02 * *$ \\
\hline First visit waiting time $6 \mathrm{~h}$ & $-0.26^{* * *}(-0.37$ to -0.14$)$ & 0.04 & & $-0.08(-0.18$ to 0.02$)$ & 0.14 & & 0.03 ** \\
\hline
\end{tabular}


Table 5. Cont.

\begin{tabular}{|c|c|c|c|c|c|c|c|}
\hline \multirow{2}{*}{$\begin{array}{c}\text { Sub-Group Facilities } \\
\text { Attribute/Level }\end{array}$} & \multicolumn{3}{|c|}{ Goodwood } & \multicolumn{3}{|c|}{ Bothasig } & \multirow{2}{*}{$\begin{array}{r}\text { Interaction Facility } \\
\text { Significance } p \text {-Value }\end{array}$} \\
\hline & Coefficient & $\begin{array}{c}\text { Estimated Standard } \\
\text { Deviation }\end{array}$ & $\begin{array}{c}\text { Relative } \\
\text { Importance }\end{array}$ & Coefficient & $\begin{array}{l}\text { Estimated Standard } \\
\text { Deviation }\end{array}$ & $\begin{array}{c}\text { Relative } \\
\text { Importance }\end{array}$ & \\
\hline Given different date appointment & $0.08(-0.10$ to 0.26$)$ & & $7.8 \%$ & $-0.24 * *(-0.42$ to -0.06$)$ & & $22 \%$ & \\
\hline \multicolumn{8}{|l|}{ Appointment Waiting time } \\
\hline Appointment waiting time $2 \mathrm{~h}$ & $0.20^{* * *}(0.05$ to 0.36$)$ & $0.33^{* * *}$ & $11.8 \%$ & $0.28^{* * *}(0.14$ to 0.43$)$ & 0.19 & & 0.30 \\
\hline Appointment waiting time $4 \mathrm{~h}$ & $0.21^{* * *}(0.09$ to 0.33$)$ & $0.35^{* * *}$ & & $0.08(-0.03$ to 0.19$)$ & 0.05 & & 0.34 \\
\hline Appointment waiting time $8 \mathrm{~h}$ & $-0.36^{* * *}(-0.53$ to -0.19$)$ & & & $-0.43^{* * *}(-0.58$ to -0.28$)$ & & $29 \%$ & \\
\hline \multicolumn{8}{|l|}{ Treatment by doctors or nurses } \\
\hline Treatment offered by nurses & $-0.01(-0.16$ to 0.13$)$ & & & $-0.24(-0.38$ to -0.10$)$ & & & \\
\hline Treatment offered by doctor & $0.01(-0.13$ to 0.16$)$ & 0.00 & $0.4 \%$ & $0.24^{* * *}(0.10$ to 0.38$)$ & $0.25^{* * *}$ & $20 \%$ & $0.02 * *$ \\
\hline \multicolumn{8}{|l|}{ Availability of medication } \\
\hline Some of the medication required is available & $-1.62(1.31$ to 1.93$)$ & & & $-0.29 * *(0.06$ to 0.52$)$ & & & \\
\hline All medication required is available & $1.33^{* * *}(1.06$ to 1.61$)$ & $1.14^{* * *}$ & $62.0 \%$ & $0.16(-0.04$ to 0.36$)$ & $0.65^{* * *}$ & $19 \%$ & $0.00 * * *$ \\
\hline
\end{tabular}

*** Significant at $0.01 ; * *$ Significant at 0.05 ; and * Significant at 0.1 . 


\section{Discussion}

The present study aimed to incorporate patient voices to identify areas in which the experience of care at public health facilities can be improved. The purpose is to facilitate demand for services, and to increase patient satisfaction. The study uses a DCE to address patient preferences in the light of the proposed implementation of National Health Insurance in South Africa [31]. We managed to identify the most preferred attributes in choosing a facility, bridging the gap in the stated preferences on the topic studied in South Africa. Ours is the second DCE study investigating understanding public facility choice in the Western Cape and South Africa. In addition, there was strength in including a sample of patients at the facilities as participants who captured preferences of individuals experiencing and were able to attest to the service provided at the facility, unlike the Honda et al. [5] study that facilitated a DCE with the community setting.

The availability of medication was the most important relative attribute when selecting a health facility. The findings were consistent with Honda et al. [5], of which drug availability was identified as the most important issue. The literature demonstrates treatment measures to be the most important factors that affect healthcare seeking [28]. This study reveals that patients have preferences for certain characteristics of health facilities: near (short distances to health facility), with absolute confidentiality during visits, with short first visit waiting and appointment waiting time, where treatment is offered by doctors, and where all required medication is available.

Distance to health facilities has been argued to influence major health outcomes [42-46]. Universal access to health care requires service availability and accessibility. Therefore, distance to health facilities is a critical component of accessibility. Our study findings showed that patients generally prefer health facilities near households across facilities and demographic characteristics. However, studies in literature [42,44-46] showed that the relationship between distance and facility selection in urban settings could be less clear as women were cited as having more health service options within reasonable travel distance compared with men. The latter can explain higher preferences for facilities that are close by.

Our study findings also revealed that participants preferred to be treated by a doctor than a nurse; similar results were also recorded in a DCE by Caldow et al. [47], who reported that it is most important for respondents to see a general practitioner (GP) rather than a practice nurse. In our study, women reported appointment waiting time as the most important attribute when selecting a health facility. A previous DCE supported this, with a cohort of women that noted appraisals of the quality of care depended vigorously on the care process and nature of the services received rather than infrastructure [48].

Pedersen et al. [49], in their DCE, identified that patients preferred short waiting times if one had an appointment. This was also true in our study for both first visit waiting time and appointment waiting time. In addition, this attribute was cited as more important than "distance to the practice" in a patient preference study [49]. This was also true in our study as both first visit waiting time and appointment waiting time had higher relative importance proportions than the distance to health facility attribute. In terms of waiting time, all other things being equal, patients are generally less likely to choose healthcare services with long waiting times. The finding that women more than men prefer shorter waiting times appears to be unique to our study. Literature search on similarly findings showed gender gap on waiting times is mostly concentrated on surgical waiting times. We therefore did not have any comparable study. However, we can assume this may be linked to the amount of responsibilities carried by women in households.

The structural outcomes at Goodwood were of greater concern compared with the Bothasig. Goodwood seemed to lack resources (based on observation or the participants' responses), affecting their structural outcomes. The interaction model for facilities revealed significant differences between Goodwood and Bothasig participants. More specifically, Goodwood participants gave more importance to the availability of medication, confidentiality, shorter distances, and first visit waiting times. Medication availability could suggest concern over stock-outs that require attention, re-assessing drug supply chain, and 
home delivery systems. There have been reported stock-outs in South Africa, mainly for HIV and TB drugs, associated with the scale-up of treatments [50]. As noted in Chiwire et al. [34], the focus group discussions process for selecting attributes for this study revealed an overcrowded Goodwood facility with less confidentiality during nurses' first point of patient screening. It is not surprising that the same issues were considered most important at Goodwood. Bothasig facility was less crowded and appeared to provide more confidentiality during screening. It is recommended that infrastructure and patient flow at Goodwood be re-assessed. Alternative methods to reduce overcrowding and long waiting times apart from the current deferral appointment system should also be considered. Despite the national policy on managing patient waiting time in outpatient departments [51], improvements in waiting times for first and appointment visits appear to be slow. They need to be continuously monitored and strengthened. More participants at Bothasig were educated at the diploma level and above (34.3\%) compared with $16.9 \%$ at Goodwood. There is a possibility of a correlation between education and the higher preference for treatment by a doctor at Bothasig.

This study has several limitations. The differences in facility layout and patient flow may have increased bias towards preferences from participants. Goodwood facility layout does not allow for confidentiality especially at first point of contact between health professions and patients. The space is not big enough to have the first point contact consultations to be conducted separately, hence nurses doing temperature screening and those doing medical probing will be in the same room. As a result, there were high patient volumes at Bothasig compared with Goodwood as a result of these structural differences. Secondly, external validity ensures comparability of hypothetical and actual choices [52]. As respondents are not obliged in reality to make the choices they indicate in a DCE, hypothetical bias may reduce the usefulness of DCE results [53]. However, the results in our study are not far removed from other findings and policy-targeted priority areas [25,51,54]. Lastly, facets of participants who refused to participate were not systematically collected and we were not able to do a contrast with those who participated.

The study brings in a wealth of knowledge especially in the Southern African context and specifically South Africa. To date, very few well-founded scientific studies have been conducted in South Africa and we are aware of only one study in the South African context that looked at patients' preferences especially from a trade-off point of view in the public health facility, and it concentrated on a community sample. Therefore, this study provides relevant scientific valuable information to policymakers as South Africa, like any other lowmiddle income country, is characterized by a limited health budget. Our study is further innovative in the sense that we reveal that patients are willing to accept trade-offs between the included attributes and most were thus important. Considering alternative data sources available to decision makers is important, more so for them to understand how useful DCEs are in predicting behavior. The quantification of how well DCEs predict behavior could explicitly account for uncertainty in DCE predictions [53]. DCEs can provide a relatively accurate and cost-effective option to predict individual choices [53]. The data from DCEs can then be used to quantify the relative importance of aspects of health care [48]. Therefore, this study avails information to policymakers on patients' preferences in the Western Cape, which is relatively accurate. Thus, accounting for the variation in DCE prediction accuracy in this manner would make for more robust uptake and impact models.

\section{Conclusions}

The study findings show overall availability of medication is the most important factor in choosing a facility for service provision. Shorter waiting times were preferred either on appointment or first visit. Being treated by doctors was significantly preferred to being treated by nurses, while the shorter distance to facility and confidentiality were highly preferred. Decision makers must include these patient voices in improving healthcare provision and increasing patient satisfaction. 
Author Contributions: Conceptualization, P.C., M.H., S.M.E. and H.M.; methodology, P.C., S.M.E., H.M. and M.H.; software, P.C., M.H. and C.B.; validation, P.C., C.B., M.H., S.M.E. and H.M.; formal analysis, P.C., M.H. and C.B.; investigation, P.C.; data curation, P.C., M.H. and C.B.; writing-original draft preparation, P.C.; writing-review and editing, M.H., S.M.E. and H.M.; visualization, P.C.; supervision, M.H., S.M.E. and H.M.; and project administration; P.C. All authors have read and agreed to the published version of the manuscript.

Funding: This research received no external funding.

Institutional Review Board Statement: The study was conducted according to the guidelines of the Declaration of Helsinki and approved by the Health Research Ethics Committee of Stellenbosch University (protocol code S17/10/208, accessed on 30 November 2017). In line with Western Cape Government Research guidelines, the Western Cape Government: Health's Provincial Health Research Committee for facilities access approval was sought and granted (protocol code WC_201712_004, accessed on 12 December 2017)

Informed Consent Statement: Informed consent was obtained from all participants involved in the study.

Data Availability Statement: The data presented in this study are available on request from the corresponding author.

Acknowledgments: The authors would like to thank all those who made the research possible.

Conflicts of Interest: The authors declare no conflict of interest. 


\section{Appendix A}

Table A1. Demographics by sub-groups.

\begin{tabular}{|c|c|c|c|c|c|c|c|c|c|c|}
\hline \multirow[b]{2}{*}{ Variables } & \multirow{2}{*}{ All $(n=466)$} & \multicolumn{3}{|c|}{ Facility } & \multicolumn{3}{|c|}{ Gender } & \multicolumn{3}{|c|}{ Age } \\
\hline & & $\begin{array}{c}\text { Bothasig CDC } \\
(\mathrm{n}=\mathbf{2 3 0})\end{array}$ & $\begin{array}{l}\text { Goodwood CDC } \\
(n=236)\end{array}$ & $p$-Value & $\begin{array}{c}\text { Women } \\
(\mathrm{n}=282)\end{array}$ & $\begin{array}{c}\text { Men } \\
(\mathrm{n}=179)\end{array}$ & $p$-Value & $\begin{array}{c}18-34 \\
(\mathrm{n}=192)\end{array}$ & $\begin{array}{c}35+ \\
(n=274)\end{array}$ & $p$-Value \\
\hline $\operatorname{Sex}(\%)$ & & & & & 1 & 1 & I & & & \\
\hline Male & $179(38.4)$ & $81(35.2)$ & $98(41.5)$ & 0.024 & / & / & & $62(32.3)$ & $117(42.7)$ & 0.003 \\
\hline Female & $282(60.5)$ & $149(64.8)$ & $133(56.4)$ & & & & & $125(65.1)$ & $157(57.3)$ & \\
\hline \multicolumn{11}{|l|}{ Age group (\%) } \\
\hline $18-34$ & $192(41.2)$ & $114(49.6)$ & $78(33.1)$ & $<0.001$ & $125(44.3)$ & $62(34.6)$ & 0.003 & / & / & / \\
\hline $35+$ & $274(58.8)$ & $116(50.4)$ & $158(66.9)$ & & $157(55.7)$ & $117(65.4)$ & & / & / & \\
\hline \multicolumn{11}{|l|}{ Marital status (\%) } \\
\hline Single & $164(35.2)$ & $82(35.7)$ & $82(34.7)$ & 0.931 & $99(35.1)$ & $65(36.3)$ & $<0.001$ & $111(57.8)$ & $53(19.3)$ & $<0.001$ \\
\hline Married or partnership & $214(45.9)$ & $106(46.1)$ & $108(45.8)$ & & $123(43.6)$ & $91(50.8)$ & & $64(33.3)$ & $150(54.7)$ & \\
\hline Widowed & $28(6.0)$ & $13(5.7)$ & $15(6.4)$ & & $24(8.5)$ & $4(2.2)$ & & $2(1.0)$ & $26(9.5)$ & \\
\hline Separated & $6(1.3)$ & $4(1.7)$ & $2(0.8)$ & & $3(1.1)$ & $3(1.7)$ & & $3(1.6)$ & $3(1.1)$ & \\
\hline \multicolumn{11}{|l|}{ Education (\%) } \\
\hline Grade $0-7$ & $32(6.9)$ & $12(5.2)$ & $20(8.5)$ & 0.022 & $21(7.4)$ & $11(6.1)$ & $<0.001$ & $3(1.6)$ & $29(10.6)$ & $<0.001$ \\
\hline Grade 8-12 & $296(63.5)$ & $137(59.6)$ & $159(67.4)$ & & $191(67.7)$ & $105(58.7)$ & & $120(62.5)$ & $176(64.2)$ & \\
\hline $\begin{array}{l}\text { National Qualifications } \\
\text { Framework (NQF, diploma or } \\
\text { certificate) }\end{array}$ & $80(17.2)$ & $52(22.6)$ & 28 (11.9) & & 39 (13.8) & $41(22.9)$ & & $40(20.8)$ & $40(14.6)$ & \\
\hline Bachelor's degree & $43(9.2)$ & $24(10.4)$ & $19(8.1)$ & & $26(9.2)$ & $17(9.5)$ & & $20(10.4)$ & $23(8.4)$ & \\
\hline Master's Degree & $8(1.7)$ & $3(1.3)$ & $5(2.1)$ & & $3(1.1)$ & $5(2.8)$ & & $3(1.6)$ & $5(1.8)$ & \\
\hline
\end{tabular}


Table A1. Cont.

\begin{tabular}{|c|c|c|c|c|c|c|c|c|c|c|}
\hline \multirow[b]{2}{*}{ Variables } & \multirow[b]{2}{*}{ All $(n=466)$} & \multicolumn{3}{|c|}{ Facility } & \multicolumn{3}{|c|}{ Gender } & \multicolumn{3}{|c|}{ Age } \\
\hline & & $\begin{array}{c}\text { Bothasig CDC } \\
(\mathrm{n}=230)\end{array}$ & $\begin{array}{c}\text { Goodwood CDC } \\
(n=236)\end{array}$ & $p$-Value & $\begin{array}{c}\text { Women } \\
(n=282)\end{array}$ & $\begin{array}{c}\text { Men } \\
(n=179)\end{array}$ & $p$-Value & $\begin{array}{c}18-34 \\
(n=192)\end{array}$ & $\begin{array}{c}35+ \\
(\mathrm{n}=274)\end{array}$ & $p$-Value \\
\hline \multicolumn{11}{|l|}{ Employment (\%) } \\
\hline Student & $34(7.3)$ & $17(7.4)$ & $17(7.2)$ & 0.034 & $24(8.5)$ & $10(5.6)$ & $<0.001$ & $33(17.2)$ & $1(0.4)$ & $<0.001$ \\
\hline Unemployed & $205(44.0)$ & $86(37.4)$ & $119(50.4)$ & & $136(48.2)$ & 69 (38.5) & & $52(27.1)$ & $153(55.8)$ & \\
\hline Self-employed & $53(11.4)$ & $31(13.5)$ & $22(9.3)$ & & $21(7.4)$ & 32 (17.9) & & $16(8.3)$ & 37 (13.5) & \\
\hline
\end{tabular}

$p$-values obtained with $\mathrm{Chi}^{2}$ test; 5 missing data for gender; 8 missing data for marital status; 7 missing data for education; and 9 missing data for employment.

\section{Appendix B}

Table A2. Access-related variables by facility, gender, and age.

\begin{tabular}{|c|c|c|c|c|c|c|c|c|c|c|}
\hline \multirow{3}{*}{ Variables } & \multirow{3}{*}{ All $(n=466)$} & \multicolumn{6}{|c|}{ Access-Related Variables } & \multirow{2}{*}{\multicolumn{3}{|c|}{ Age }} \\
\hline & & \multicolumn{3}{|c|}{ Facility } & \multicolumn{3}{|c|}{ Gender } & & & \\
\hline & & $\begin{array}{c}\text { Bothasig CDC } \\
(\mathrm{n}=230)\end{array}$ & $\begin{array}{c}\text { Goodwood CDC } \\
(\mathrm{n}=236)\end{array}$ & $p$-Value & $\begin{array}{c}\text { Women } \\
(\mathrm{n}=282)\end{array}$ & $\begin{array}{c}\text { Men } \\
(n=179)\end{array}$ & $p$-Value & $\begin{array}{c}18-34 \\
(\mathrm{n}=192)\end{array}$ & $\begin{array}{c}35+ \\
(\mathrm{n}=274)\end{array}$ & $p$-Value \\
\hline \multicolumn{11}{|l|}{ Facility visit } \\
\hline First time & $54(11.6)$ & $37(16.1)$ & $17(7.2)$ & $<0.001$ & $26(9.2)$ & $28(15.6)$ & 0.161 & $31(16.1)$ & $23(8.4)$ & $<0.001$ \\
\hline Between 1-12 months & $120(25.8)$ & $77(33.5)$ & $43(18.2)$ & & $75(26.6)$ & $45(25.1)$ & & $68(35.4)$ & $52(19.0)$ & \\
\hline Between $1-2$ years & $74(15.9)$ & $48(20.9)$ & $26(11.0)$ & & $43(15.2)$ & $31(17.3)$ & & $29(15.1)$ & $45(16.4)$ & \\
\hline 2 years and above & $208(44.6)$ & $65(28.3)$ & $143(60.6)$ & & $134(47.5)$ & $74(41.3)$ & & $58(30.2)$ & $150(54.7)$ & \\
\hline \multicolumn{11}{|l|}{ Chronic } \\
\hline Chronic & $203(43.6)$ & $89(38.7)$ & $114(48.3)$ & 0.097 & $120(42.6)$ & $83(46.4)$ & 0.073 & $44(22.9)$ & $159(58.0)$ & $<0.001$ \\
\hline One-off & $236(50.6)$ & $127(55.2)$ & $109(46.2)$ & & $151(53.5)$ & $85(47.5)$ & & $135(70.3)$ & $101(36.9)$ & \\
\hline Both & $10(2.1)$ & $4(1.7)$ & $6(2.5)$ & & $3(1.1)$ & $7(3.9)$ & & $1(0.5)$ & $9(3.3)$ & \\
\hline
\end{tabular}


Table A2. Cont.

\begin{tabular}{|c|c|c|c|c|c|c|c|c|c|c|}
\hline \multirow{3}{*}{ Variables } & \multirow{3}{*}{ All $(n=466)$} & \multicolumn{6}{|c|}{ Access-Related Variables } & \multirow{2}{*}{\multicolumn{3}{|c|}{ Age }} \\
\hline & & \multicolumn{3}{|c|}{ Facility } & \multicolumn{3}{|c|}{ Gender } & & & \\
\hline & & $\begin{array}{c}\text { Bothasig CDC } \\
(\mathrm{n}=230)\end{array}$ & $\begin{array}{c}\text { Goodwood CDC } \\
(n=236)\end{array}$ & $p$-Value & $\begin{array}{c}\text { Women } \\
(\mathrm{n}=282)\end{array}$ & $\begin{array}{c}\text { Men } \\
(\mathrm{n}=179)\end{array}$ & $p$-Value & $\begin{array}{c}18-34 \\
(\mathrm{n}=192)\end{array}$ & $\begin{array}{c}35+ \\
(\mathrm{n}=274)\end{array}$ & $p$-Value \\
\hline \multicolumn{11}{|l|}{ Transport } \\
\hline Walking & $186(39.9)$ & $58(25.2)$ & $128(54.2)$ & $<0.001$ & $105(37.2)$ & $81(45.3)$ & 0.283 & $74(38.5)$ & $112(40.9)$ & 0.249 \\
\hline Public taxi & $72(15.5)$ & $31(13.5)$ & $41(17.4)$ & & $52(18.4)$ & $20(11.2)$ & & 37 (19.3) & $35(12.8)$ & \\
\hline Private taxi & $12(2.6)$ & $7(3.0)$ & $5(2.1)$ & & $8(2.8)$ & $4(2.2)$ & & $5(2.6)$ & $7(2.6)$ & \\
\hline Bus & $16(3.4)$ & $12(5.2)$ & $4(1.7)$ & & $10(3.5)$ & $6(3.4)$ & & $7(3.6)$ & $9(3.3)$ & \\
\hline Private car & $170(36.5)$ & $119(51.7)$ & $51(21.6)$ & & $104(36.9)$ & $66(36.9)$ & & $61(31.8)$ & $109(39.7)$ & \\
\hline Ambulance & $1(0.2)$ & $1(0.4)$ & $0(0.00)$ & & $1(0.4)$ & $0(0.00)$ & & $1(0.5)$ & $0(0.00)$ & \\
\hline \multicolumn{11}{|l|}{ Travel time } \\
\hline 0-15 min & $246(52.8)$ & $128(55.7)$ & $118(50.0)$ & 0.208 & $154(54.6)$ & $92(51.4)$ & 0.645 & $101(52.6)$ & $145(52.9)$ & 0.905 \\
\hline $15-30 \mathrm{~min}$ & $140(30.0)$ & $66(28.7)$ & $74(31.4)$ & & $85(30.1)$ & $55(30.7)$ & & $55(28.6)$ & $85(31.0)$ & \\
\hline $30 \mathrm{~min}$ to $1 \mathrm{~h}$ & $51(10.9)$ & $19(8.3)$ & $32(13.6)$ & & $30(10.6)$ & $21(11.7)$ & & $19(9.9)$ & $32(11.7)$ & \\
\hline More than $1 \mathrm{~h}$ & $11(2.4)$ & $7(3.0)$ & $4(1.7)$ & & $8(2.8)$ & $3(1.7)$ & & $4(2.1)$ & $7(2.6)$ & \\
\hline
\end{tabular}

$p$-values obtained with $\mathrm{Chi}^{2}$ test; 10 missing data for facility visit; 16 missing data for chronic; 9 missing data for transport; 17 missing data for travel time (+1 wrong data entered/coded as 5); and 8 missing data for home residence. 


\section{Appendix C}

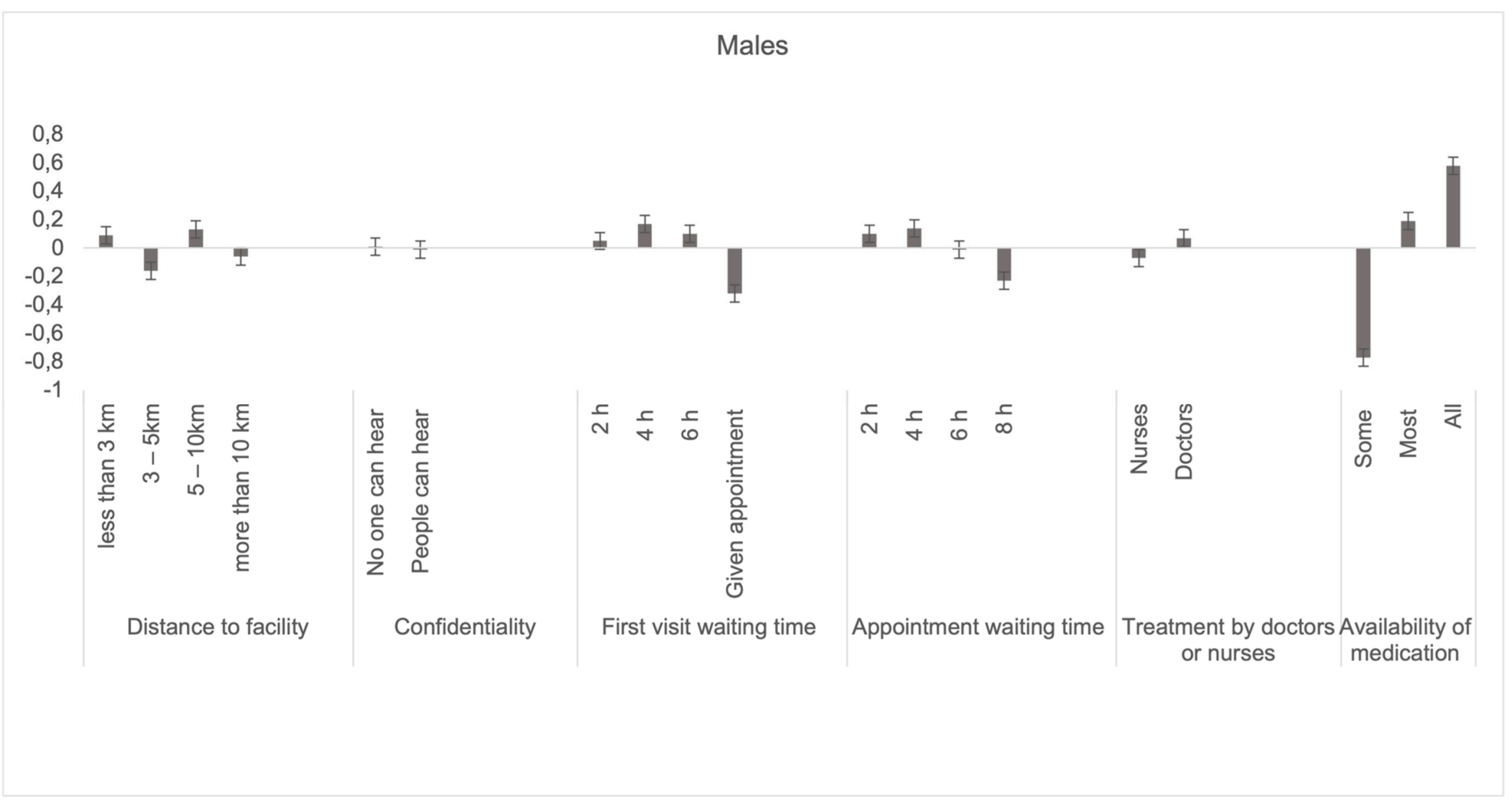

Figure A1. Cont. 


\section{Females}

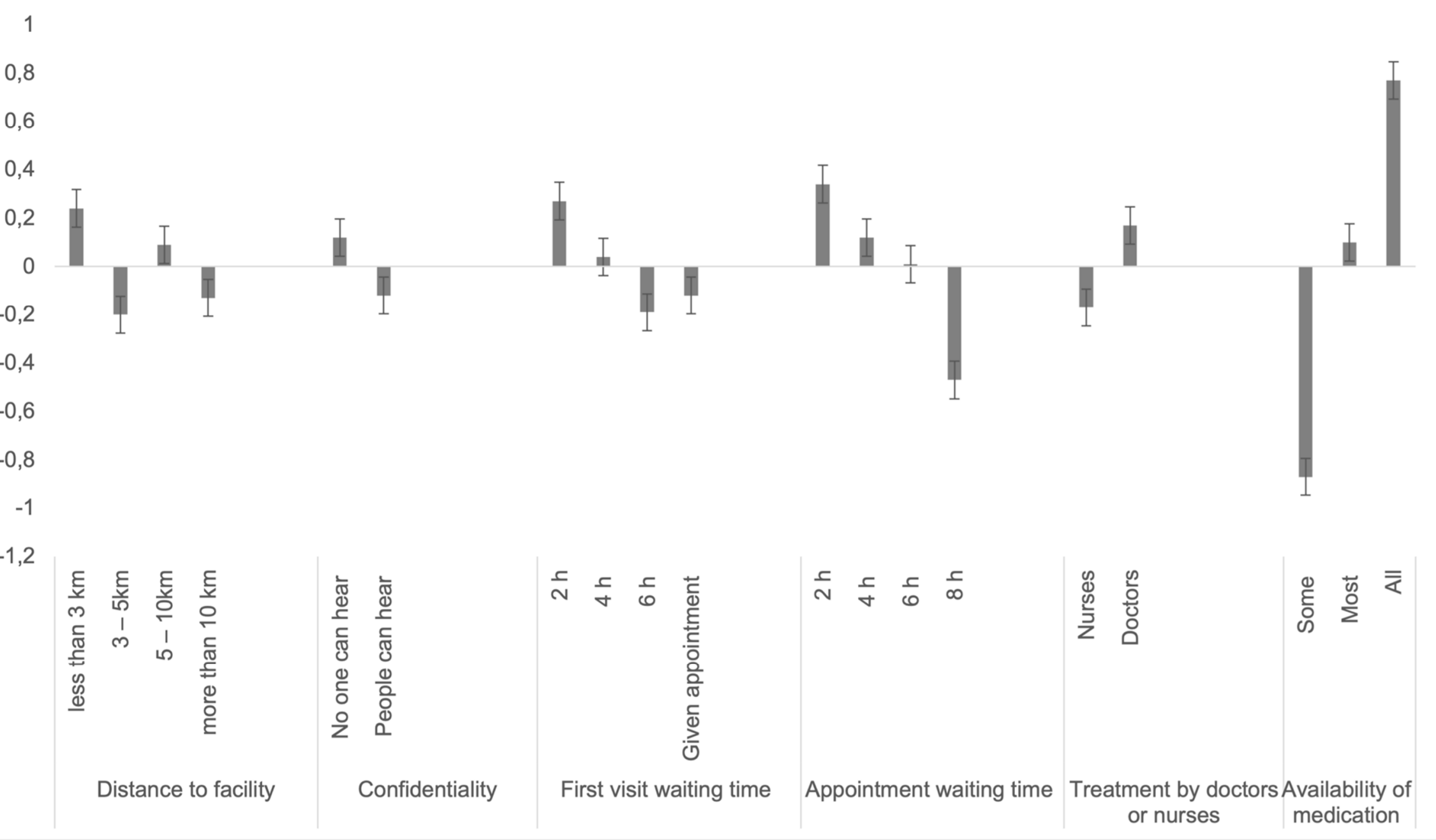

Figure A1. Sub-group analysis males vs. females. 


\section{Appendix D}

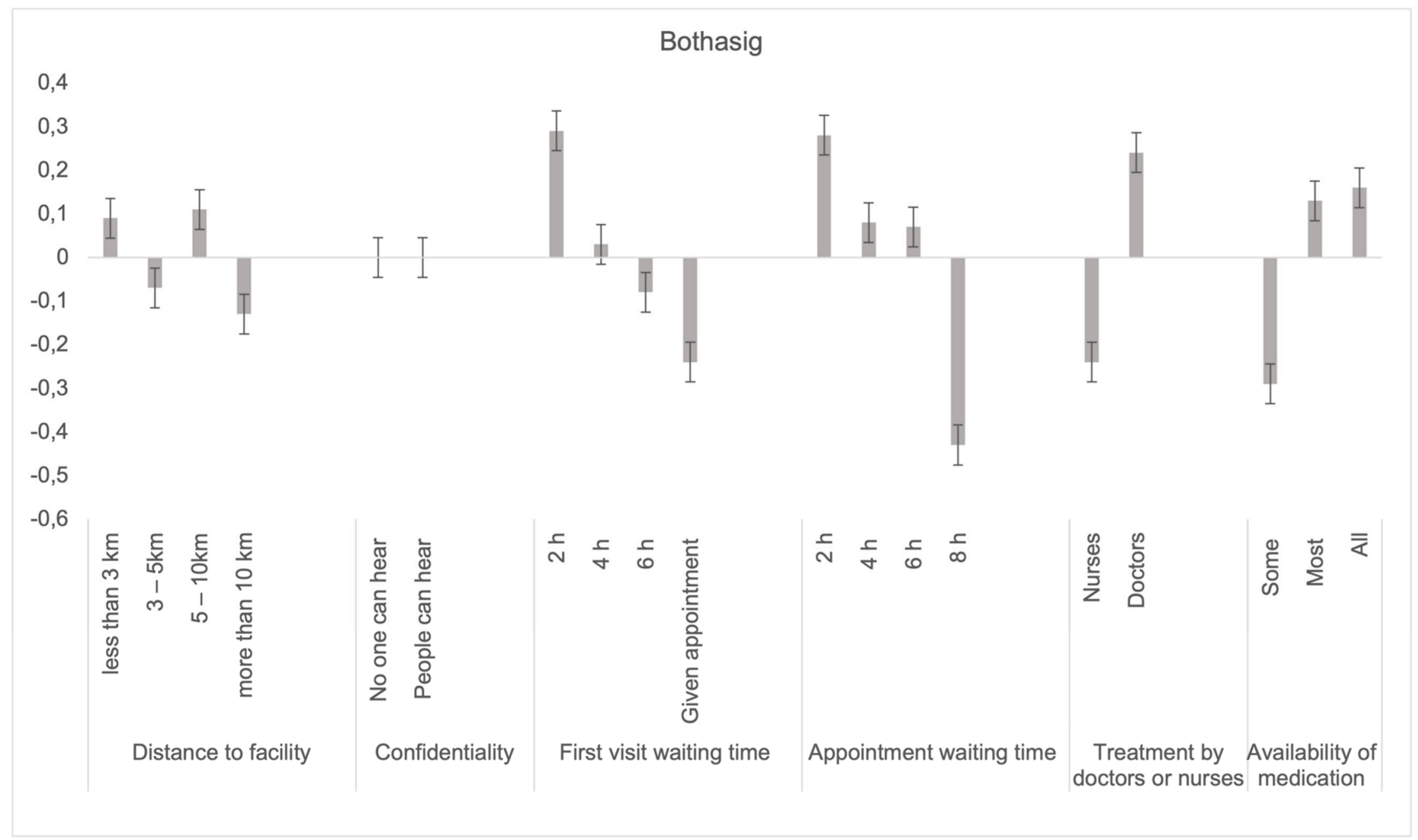

Figure A2. Cont. 


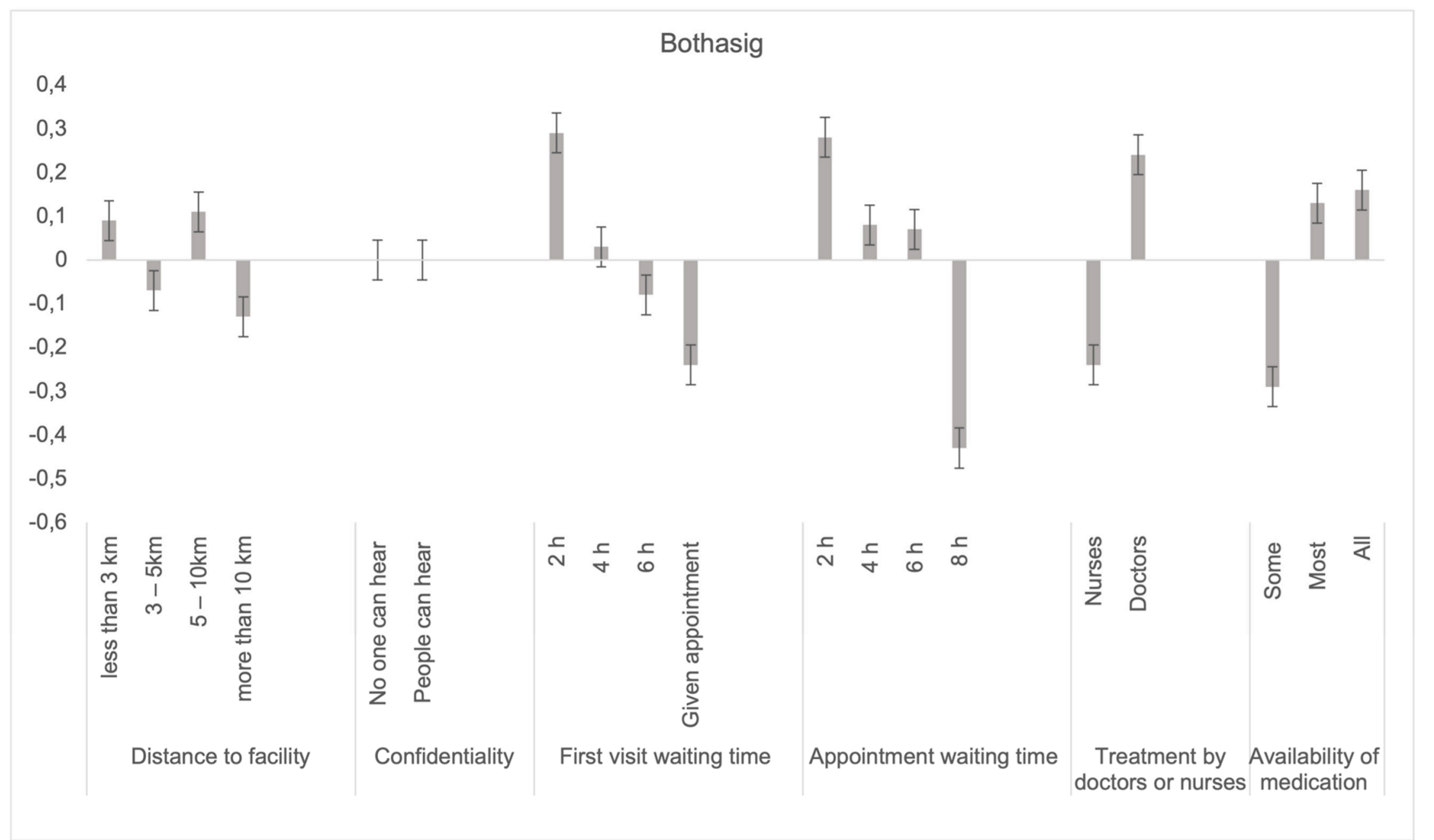

Figure A2. Sub-group analysis facilities. 


\section{References}

1. Yu, W.; Li, M.; Ye, F.; Xue, C.; Zhang, L. Patient preference and choice of healthcare providers in Shanghai, China: A cross-sectional study. BMJ Open 2017, 7, e016418. [CrossRef]

2. Cheng, B.; Li, X.; Lu, Y.; Tan, Y. Agent-based Modeling and Simulation Research into Residents Healthcare Choice. Syst. Eng. 2009, 27, 96-101.

3. Mahlathi, P.; Dlamini, J. Minimum data sets for human resources for health and the surgical workforce in South Africa's health system: A rapid analysis of stock and migration. Afr. Inst. Heal. Leadersh. Dev. 2015. Available online: https: //www.who.int/workforcealliance/031616south_africa_case_studiesweb.pdf (accessed on 12 November 2021).

4. World Health Organization The World Health Report 2000-Health Systems: Improving Performance; World Health Organization: Geneva, Switzerland, 2000; Volume 78.

5. Honda, A.; Ryan, M.; Van Niekerk, R.; McIntyre, D. Improving the public health sector in South Africa: Eliciting public preferences using a discrete choice experiment. Health Policy Plan. 2015, 30, 600-611. [CrossRef]

6. Dear South Africa Call for Public Comment on NHI Bill. Available online: https://dearsouthafrica.co.za/national-healthinsurance-bill-2019/ (accessed on 12 November 2021).

7. Parlimentary Communication Services Media Alert: Committee on Health To Continue Public Hearings on Nhi Bill. Available online: https://www.parliament.gov.za/press-releases/media-alert-committee-health-continue-public-hearings-nhi-bill. (accessed on 12 November 2021).

8. Isaacs, J. Critical Assessment of Public Participation in Enhancing Governance in South Africa: A Case Study of Selected Community Health Committees in Cape Town, Mitchell's Plain. 2016. Available online: https://www.academia.edu/383357 59/Critical_Assessment_of_Public_Participation_in_Enhancing_Governance_in_South_Africa_A_Case_Study_of_Selected_ Community_Health_Committees_in_Cape_Town_Mitchells (accessed on 12 November 2021).

9. House, I.; Street, K. Mid-Year Population Estimates 2017; Statistics South Africa: Pretoria, South Africa, 2017.

10. Loewenson, R. Public Participation in Health: Making People Matter. IDS Working. Paper 84 1998, IDS Collections 1451. Available online: https:/ / opendocs.ids.ac.uk/opendocs/handle/20.500.12413/3402 (accessed on 12 November 2021).

11. Gray, A.; Vawda, Y. Health policy and legislation. S. Afr. Heal. Rev. 2014, 2014, 3-19.

12. Hifinger, M.; Hiligsmann, M.; Ramiro, S.; Watson, V.; Severens, J.L.; Fautre, B.; Uhlig, T.; Van Vollenhoven, R.; Jacques, P.; Detert, J.; et al. Economic considerations and patients' preferences affect treatment selection for patients with rheumatoid arthritis: A discrete choice experiment among European rheumatologists. Ann. Rheum. Dis. 2017, 76, 126-132. [CrossRef]

13. Dirksen, C.D.; Utens, C.M.A.; Joore, M.A.; van Barneveld, T.A.; Boer, B.; Dreesens, D.H.H.; van Laarhoven, H.; Smit, C.; Stiggelbout, A.M.; van der Weijden, T. Integrating evidence on patient preferences in healthcare policy decisions: Protocol of the patient-VIP study. Implement. Sci. 2013, 8, 64-65. [CrossRef]

14. Say, R.E.; Thomson, R. The importance of patient preferences in treatment decisions—challenges for doctors. $B M J \mathbf{2 0 0 3 , 3 2 7 ,}$ 542-545. [CrossRef]

15. Salampessy, B.H.; Veldwijk, J.; Jantine Schuit, A.; van den Brekel-Dijkstra, K.; Neslo, R.E.J.; Ardine de Wit, G.; Lambooij, M.S. The Predictive Value of Discrete Choice Experiments in Public Health: An Exploratory Application. Patient 2015, 8, 521-529. [CrossRef]

16. Mulhbacher, A.C.; Bethge, S. Patients' preferences: A Discrete Choice Experiment for treatment of non-small-cell lung cancer. Eur. J. Heal. Econ. 2015, 16, 657-670. [CrossRef]

17. Brennan, P.F.; Strombom, I. Improving health care by understanding patient preferences: The role of computer technology. J. Am. Med. Informatics Assoc. 1998, 5, 257-262. [CrossRef]

18. Brittin, J.; Elijah-Barnwell, S.; Nam, Y.; Araz, O.; Friedow, B.; Jameton, A.; Drummond, W.; Huang, T.T.K. Community-engaged public health research to inform hospital campus planning in a low socioeconomic status urban neighborhood. Heal. Environ. Res. Des. J. 2015, 8, 12-24. [CrossRef]

19. Rifkin, S.B. Examining the links between community participation and health outcomes: A review of the literature. Health Policy Plan. 2014, 29, 98-106. [CrossRef]

20. Abelson, J.; Montesanti, S.; Li, K.; Gauvin, F.-P.; Martin, E. Effective Strategies for Interactive Public Engagement in the Development of Healthcare Policies and Programs; Canadian Health Services Research Foundation: Ottawa, ON, Canada, 2010.

21. Coulter, A.; Ellins, J. Effectiveness of strategies for informing, educating, and involving patients. Br. Med. J. 2007, 335, 24-27. [CrossRef]

22. Contandriopoulos, D. A sociological perspective on public participation in health care. Soc. Sci. Med. 2004, 58, 321-330. [CrossRef]

23. Conklin, A.; Morris, Z.; Nolte, E. Involving the Public in Healthcare Policy; RAND Corporation: Santa Monica, CA, USA, 2010.

24. Soekhai, V.; Whichello, C.; Levitan, B.; Veldwijk, J.; Pinto, C.A.; Donkers, B.; Huys, I.; van Overbeeke, E.; Juhaeri, J.; de BekkerGrob, E.W. Methods for exploring and eliciting patient preferences in the medical product lifecycle: A literature review. Drug Discov. Today 2019, 24, 1324-1331. [CrossRef]

25. Republic of South Africa National Department of Health. National Department of Health-National Core Standards; The Republic of South Africa: Pretoria, South Africa, 2011.

26. Kleij, K.S.; Tangermann, U.; Amelung, V.E.; Krauth, C. Patients' preferences for primary health care-A systematic literature review of discrete choice experiments. BMC Health Serv. Res. 2017, 17, 1-12. [CrossRef] 
27. Jiang, M.Z.; Fu, Q.; Xiong, J.Y.; Li, X.L.; Jia, E.P.; Peng, Y.Y.; Shen, X. Preferences heterogeneity of health care utilization of community residents in China: A stated preference discrete choice experiment. BMC Health Serv. Res. 2020, 20, 1-11. [CrossRef]

28. Jia, E.; Gu, Y.; Peng, Y.; Li, X.; Shen, X.; Jiang, M.; Xiong, J. Preferences of patients with non-communicable diseases for primary healthcare facilities: A discrete choice experiment in Wuhan, China. Int. J. Environ. Res. Public Health 2020, 17, 3987. [CrossRef]

29. Zhang, W.; Ung, C.O.L.; Lin, G.; Liu, J.; Li, W.; Hu, H.; Xi, X. Factors contributing to patients' preferences for primary health care institutions in China: A qualitative study. Front. Public Heal. 2020, 8, 414. [CrossRef]

30. Zhang, Z.; Qiu, Z. The usage pattern and spatial preference of community facilities by elder people in rural environments. J. Hous. Built Environ. 2020, 35, 661-678. [CrossRef]

31. Republic of South Africa National Department of Health. National Health Insurance Bill; The Republic of South Africa: Pretoria, South Africa, 2018; pp. 533-549.

32. Bridges, J.F.P.; Hauber, A.B.; Marshall, D.; Lloyd, A.; Prosser, L.A.; Regier, D.A.; Johnson, F.R.; Mauskopf, J. Conjoint analysis applications in health-A checklist: A report of the ISPOR Good Research Practices for Conjoint Analysis Task Force. Value Heal. 2011, 14, 403-413. [CrossRef]

33. Coast, J.; Al-Janabi, H.; Sutton, E.J.; Horrocks, S.A.; Vosper, A.J.; Swancutt, D.R.; Flynn, T.N. Using qualitative methods for attribute development for Discrete Choice Experiments: Issues and recommendations. Health Econ. 2012, 21, 730-741. [CrossRef]

34. Chiwire, P.; Evers, S.M.; Mahomed, H.; Hiligsmann, M. Identification and Prioritization of Attributes for a Discrete Choice Experiment Using the Nominal Group Technique: Patients' Choice of Public Health Facilities in Cape Town, South Africa. Value Health Reg. Issues 2021, 27, 90-98. [CrossRef]

35. Chiwire, P.; Evers, S.M.; Mahomed, H.; Hiligsmann, M. Willingness to pay for primary health care at public facilities in the Western Cape Province, Cape Town, South Africa. J. Med. Econ. 2021, 24, 162-172. [CrossRef]

36. Lancsar, E.; Louviere, J. Conducting Discrete Choice experiments to inform healthcare decision making: A user's guide. Pharmacoeconomics 2008, 26, 661-677. [CrossRef]

37. de Bekker-Grob, E.W.; Donkers, B.; Jonker, M.F.; Stolk, E.A. Sample size requirements for Discrete-Choice Experiments in healthcare: A practical guide. Patient 2015, 8, 373-384. [CrossRef]

38. Sweeney, R. Studying Preferences in Health Service Delivery: The Use of Discrete Choice Experiments; Nossal Institute, Health Policy \& Health finance Knowledge Hub: Melbourne, Australia, 2011.

39. Hifinger, M.; Hiligsmann, M.; Ramiro, S.; Severens, H.; Fautrel, B.J.; Watson, V.; Uhlig, T.; van Vollenhoven, R.; Jacques, P.; Detert, J.; et al. OP0281 Rheumatologists Consider Patient Preferences and Costs when Choosing Treatments for Rheumatoid Arthritis (RA) Patients. A Cross-European Discrete Choice Experiment. Ann. Rheum. Dis. 2015, 74, 178.2-179. [CrossRef]

40. Hiligsmann, M.M.; Bours, S.P.G.; Boonen, A. A Review of Patient Preferences for Osteoporosis Drug Treatment. Curr. Rheumatol. Rep. 2015, 17, 61. [CrossRef]

41. Hiligsmann, M.; van Durme, C.; Geusens, P.; Dellaert, B.G.C.; Dirksen, C.D.; van der Weijden, T.; Reginster, J.Y.; Boonen, A. Nominal Group Technique to select attributes for Discrete Choice Experiments: An example for drug treatment choice in osteoporosis. Patient Prefer. Adherence 2013, 7, 133-139. [CrossRef]

42. Escamilla, V.; Calhoun, L.; Winston, J.; Speizer, I.S. The Role of Distance and Quality on Facility Selection for Maternal and Child Health Services in Urban Kenya. J. Urban Heal. 2018, 95, 1-12. [CrossRef]

43. Schoeps, A.; Gabrysch, S.; Niamba, L.; Sié, A.; Becher, H. The effect of distance to health-care facilities on childhood mortality in rural Burkina Faso. Am. J. Epidemiol. 2011, 173, 492-498. [CrossRef]

44. Jordan, H.; Roderick, P.; Martin, D.; Barnett, S. Distance, rurality and the need for care: Access to health services in South West England. Int. J. Health Geogr. 2004, 3, 1-9. [CrossRef]

45. Nesbitt, R.C.; Lohela, T.J.; Soremekun, S.; Vesel, L.; Manu, A.; Okyere, E.; Grundy, C.; Amenga-Etego, S.; Owusu-Agyei, S.; Kirkwood, B.R.; et al. The influence of distance and quality of care on place of delivery in rural Ghana. Sci. Rep. 2016, 6, 1-8. [CrossRef]

46. Kadobera, D.; Sartorius, B.; Masanja, H.; Mathew, A.; Waiswa, P. The effect of distance to formal health facility on childhood mortality in rural Tanzania, 2005-2007. Glob. Health Action 2012, 5, 1-9. [CrossRef]

47. Caldow, J.; Bond, C.; Ryan, M.; Campbell, N.C.; Miguel, F.S.; Kiger, A.; Lee, A. Treatment of minor illness in primary care: A national survey of patient satisfaction, attitudes and preferences regarding a wider nursing role. Heal. Expect. 2007, 10, 30-45. [CrossRef]

48. Larson, E.; Vail, D.; Mbaruku, G.M.; Kimweri, A.; Freedman, L.P.; Kruk, M.E. Moving toward patient-centered care in Africa: A discrete choice experiment of preferences for delivery care among 3003 Tanzanian women. PLoS ONE 2015, 10, 1-12. [CrossRef]

49. Pedersen, L.B.; Kjær, T.; Kragstrup, J.; Gyrd-Hansen, D. Do general practitioners know patients' preferences? An empirical study on the agency relationship at an aggregate level using a discrete choice experiment. Value Heal. 2012, 15, 514-523. [CrossRef]

50. Hwang, B.; Shroufi, A.; Gils, T.; Steele, S.J.; Grimsrud, A.; Boulle, A.; Yawa, A.; Stevenson, S.; Jankelowitz, L.; Versteeg-Mojanaga, M.; et al. Stock-outs of antiretroviral and tuberculosis medicines in South Africa: A national cross-sectional survey. PLoS ONE 2019, 14, 1-13. [CrossRef]

51. Republic of South Africa National Department of Health. National Policy on Management of Patient Waiting Time in Out Patient Departments; National Department of Health: Pretoria, South Africa, 2015; p. 20.

52. Lancsar, E.; Swait, J. Reconceptualising the External Validity of Discrete Choice Experiments. Pharmacoeconomics 2014, 32, 951-965. [CrossRef] 
53. Quaife, M.; Terris-Prestholt, F.; Di Tanna, G.L.; Vickerman, P. How well do discrete choice experiments predict health choices? A systematic review and meta-analysis of external validity. Eur. J. Heal. Econ. 2018, 19, 1053-1066. [CrossRef]

54. Hunter, J.R.; Asmall, S.; Ravhengani, N.M.; Chandran, T.M.; Tucker, J.; Mokgalagadi, Y. The Ideal Clinic in South Africa: Progress and challenges in implementation. S. Afr. Heal. Rev. 2016, 2017, 111-124. 